\title{
The Examination of Public Education Center Trainers' Attitudes towards Social Media and Their Self-Efficacy in Social Networks for Instructional Purposes
}

\author{
Cavit ERDOĞMUŞ \\ Amasya University, Science Institute, Department of Computer Education and Instructional \\ Technology, Amasya, Turkey
}

\section{Özgen KORKMAZ*}

Amasya University, Technology Faculty, Department of Computer Engineering, Amasya, Turkey

\section{Recep ÇAKIR}

Amasya University, Education Faculty, Department of Computer Education and Instructional Technology, Amasya, Turkey

\section{Feray UĞUR-ERDOĞMUŞ}

Amasya University, Education Faculty, Department of Computer Education and Instructional Technology, Amasya, Turkey

\section{Article history}

Received:

18.02.2019

Received in revised form: 08.05.2019

\section{Accepted:}

13.05.2019

Key words:

Public Education Center, Social Media, Educational Social Network Self-Efficacy
The aim of this research is to examine the attitudes of public education center trainers to social media in terms of demographic (age, gender, education, etc.) characteristic and their self-efficacy in social networks for instructional purposes. In this study, quantitative and qualitative data were collected by using mixed method study. The study group was consisted of volunteer educators working in Suluova Public Education Center in Turkey. Results of this study showed that teachers' attitudes towards social media and their self-efficacy perceptions towards the instructional use of social media were higher. With respect to demographic characteristics, their attitudes towards social media showed differentiation in terms of gender and education, and no differentiation was observed in terms of other characteristics. There was a significant difference in the educational status and marital status characteristics of the trainers' self-efficacy for educational uses of social networks. There was a positive correlation between the attitudes of the instructors towards social media and their self-efficacy for educational uses of social networks. Perceptions of the instructors regarding social media were mostly positive. Participants stated that they used social media for communication, professional and personal development as well as follow-up, liking, sharing feelings and thoughts, personal presentation and training purposes. 


\section{Introduction}

In parallel with rapid advancements in science, technology, society and culture, the attributed importance of information is increasing. Individuals try to enhance and update their knowledge according to their interests in order to fully become adapted to these developments and also to the expectations of an ever changing society. Changes and developments in technology; the demand for better managerial organizations and the knowledge pertaining to this, and the dazzling developments in the world have sparked interest in the concept of lifelong learning, especially in terms of speeding up of the development of any necessary skills (Cheallaigh, 2001). In fact, individuals can achieve this goal through lifelong learning. Ministry of National Education (MoNE) (2018) defines lifelong learning as a term encompassing informal learning activities of any sort attended throughout life "in order to improve the knowledge, skills and competencies of individuals for social and employment purposes" (p.1). What Alfred North Whitehead pointed out in the 1930s, i.e. that people learn what they learn in their youth, has recently become highly invalid. Today, changes of crucial importance occur 'in the blink of an eye'. Therefore, any training to be provided for indivuals should ensure that they are well prepared for novel conditions yet to come (Ret: Akbaş \& Özdemir, 2002). Aktan (2007) stated that lifelong learning refers to learning from early ages until the end of life, and also underpinned that it includes all kinds of non-formal education (family education, community learning etc.) different from formal learning (education received in primary and secondary education institutions, higher education organizations and so on). Individuals, who are outside of formal education, can benefit from the Public Education Centers, which are the basic components of lifelong learning institutions, in order to increase their levels of knowledge. Public Education Centers (HEM) is defined by MoNE (2018) as "the institutions in which lifelong learning courses and educational activities are organized" (p.1). The task of conducting public education activities in our country has been authorised to the General Directorate of Lifelong Learning of the MoNE. Public Education Centers constitute the provincial organizations of the General Directorate. In Turkey, today 986 (Turkey Statistics Institute [TurkStat], 2018) Public Education Centers provide the society with opportunities for learning, self-development and abilities that are vital to be able to seek professions in many areas. The indispensable elements of this process, of course, are those who give training in Public Education Centers. In all the areas of the $21^{\text {st }}$ century, known also as the information and technology age, social media is so elemental that education without any uses of social media cannot be envisaged. According to Jones, Blackey, Fitzgibbon and Chew (2010), social media is not just a technology or computer system. It is an ideal environment that directs students / instructors to reflect on their own learning and teacher practices (Jones et al., 2010). Social media also provides an environment for instructors and students to improve learning and teaching experiences (Jones et al., 2010). Social media is so effective that it makes it necessary for Public Education Center trainers to refer to it during the relevant processes they are engaged in.

Boyd shared the simplest definition of social media as the whole of the applications that allow individuals to interact with the Internet through Technologies $(2008$, p. 92). According to Öztürk and Talas (2015), all communication, interaction and mutual data exchange of the individuals in the society on the internet constitute the social media. Websites and applications such as social networks, blogs, communication and sharing sites to share content and information enable individuals to easily reach the content they need (Öztürk \& Talas, 2015). It can be observed that the number of individuals who share content is on a dramatic increase due to the rapid boost in the amount of shared information and content. According to Egüz and Kesten (2018), with a view to pledging to meet the educational needs of individuals, 
social media has become a frequently used tool in accessing information. In the relevant literature, self-efficacy is witnessed as one of the concepts that predicates a person's own skills and abilities (Axboe, Mette, Christensen, Kaj, Kofoed, Poul-Erik \& Ammentorp, Jette 2016: 2) and as an element constituting the basis of social learning theory (Morgil, İnci, Seçken, Nilgün \& Yücel, A.Seda 2004: 63). It indeed is a critical component of social cognitive theory that has an impact on human thought, motivation, action and performance. According to Stajkovic and Luthans (1998), self-efficacy is one of the most important psychological mechanisms to stimulate positive work-related outputs. According to Bandura (1997), self-efficacy is expressed as the belief in the capacity of individuals to demonstrate their expected successes. Luszcynska, Aleksandra, Gutie’Rrez-Don A, Benicio \& Schwarzer, Ralf (2005: 82) describes self-efficacy as the sum of beliefs that people have in their ability to control their demands and the functioning of these demands.

It is observed in the bulk of research that the use of social media has a drastic increase in uses for educational purposes through social networks in educational settings. As Şişman-Eren (2014) stated, social media practices create an up-to-date dimension within education and learning processes as well as methods. Due to its flexible use and widespread nature, social networking sites, which are created by social media, ensure opportunities of generating communities, as well as chances of sharing and giving feedback for instructors and students (Öztürk, Öztürk \& Özen, 2016). In addition to all of these features, social media and rich teaching methods emerging in the field of education has a symbiotic relationship since social media supports learning processes, notably enabling better evaluation of learner performance (Jones et al., 2010). Accordingly administrators, educators and students need to improve themselves in the field of educational social media in order not to fall behind the developments and changes taking place as regards information technologies. As the number of social media users is so high and will continue to increase rapidly, it has become important for educational administrators and teachers to make use of social media tools to better their instructional knowledge and practices (Özmen, Aküzüm, Sünkür \& Baysal, 2012).

In this respect, it can be said that social networks in educational settings are preferred by the relevant parties. Therefore, it is necessary for all the stakeholders like school administrators, teachers and students to use social networks for educational purposes in an effective manner to be able to keep up with the rapid developments and changes in information technologies. In this context, due to the high number of social network users, it is becoming increasingly important in particular for instructors to resort to these tools for their professional development (Özmen, et al, 2012). According to Şişman-Eren (2014), studies on the use of social media in education show that social media applications positively add to the computational abilities of individuals as they go on having access to information, taking part in content creation, exchanging information and communicating with others. Taking a closer look at the literature, it can be highlighted that there are varying results according to the gender, age and marital status of educators' social media usage and their attitudes. In the study of Alakurt (2016), there was no significant difference reported in relation to gender, age or marital status of the aforementioned individuals. Similarly, according to Acar and Yenmiş (2014), there was no significant difference spotted re. gender or age. Nevertheless, it is concluded in some other studies that there are actually significant differences with reference to the above characteristics (Koçak, 2012; Aydın \& Çelik, 2017). From this angle, this research can contribute to the literature since the aim here is studying and revealing the views of the public education center instructors about using social media, their attitudes towards it and the relationship between social networks' instructional use self-efficacy and the opinions of educators about social media. Research questions of this study are: 
(1) What are the attitudes of instructors towards social media and the self-efficacy of social networks?

(2) Are the attitudes of the instructors towards social media and the educational capacity of social networks differentiated by gender?

(3) Are the attitudes of the instructors towards social media and the self-efficacy of the social networks differentiated by age?

(4) Are the attitudes of the instructors towards social media and the educational capacities of the social networks differentiated according to their educational status?

(5) Do instructors' attitudes towards social media and the self-efficacy of social networks differ according to their marital status?

(6) Is there a relationship between the attitudes of instructors towards social media and the self-efficacy of social networks?

(7) What are the opinions of instructors on general and educational uses of social media?

\section{Method}

\section{Research Design}

In this mixed study, both quantitative and qualitative research methods were used. Onwuegbuzie and Collins (2007) defined the mixed method as a method where the quantitative data is analysed together with the qualitative data after the latter is obtained and a link between the results is created and interpreted. An explanatory sequential mixed-methods design was selected here, and therefore the study involved collecting and analyzing quantitative data initially and then explaining and expanding upon the quantitative results using qualitative data collected became possible. The overall purpose was to explore both the depth and breadth of what the scope of the research problem could bring. The quantitative results helped identify qualitative research questions and guided the sampling of the interviewed participants. Within the scope of descriptive research, quantitative data were collected by using questionnaires and scales. "Descriptive research depicts a given situation as precisely and carefully as possible. The most common descriptive method in research in the field of education is the screening study because researchers summarize the characteristics of individuals, groups or physical environments" (Büyüköztürk, Kılıç Çakmak, Akgün, Karadeniz \& Demirel, 2016). In these research types, the frequency of repeating the characteristics of a given universe is analyzed in detail and the results are analyzed in detail (Aziz, 1994).

\section{Study Group}

The study group of this research consists of volunteer trainers who are working as instructors in Suluova Public Education Center in year 2018. The participation was designated by convenient sampling method. The distribution of the study group by gender and age is summarized in Table 1.

Table 1. Distribution of Study Groups by Gender and Age

\begin{tabular}{|c|c|c|c|c|}
\hline & & & & Total \\
\hline & & $\begin{array}{c}18-30 \\
\end{array}$ & $41-50$ & \\
\hline & Male & 16 & 5 & 21 \\
\hline Gender & Female & 20 & 13 & 33 \\
\hline Total & & 36 & 18 & 54 \\
\hline
\end{tabular}




\section{Data Collection Tools}

One of the data collection tools exploited in this research was Personal Information Form, consisting of 9 items, which was developed by the researcher and aimed to collect information about the characteristics of participants.

In order to determine the attitudes of the participants towards social media during the study, "The Attitude Scale on Social Media" by Otrar and Argin (2015), consisting of 23 items and 5-point Likert type scale was used. 23 problems in the scale comprise 17 positive items and 6 negative items. Scale has 4 sub-dimensions. These dimensions are "Need for Sharing", "Social Competence", "Social Isolation" and "Relationship with Teachers". The total variance of the scale used was $52.65 \%$. As a result of the vertical factor rotation analysis, the factor loadings of the substances ranged from 0.476 to 0.892 . The item total coefficients ranged from 0.30 to 0.65 , and the residual coefficients ranged from 0.25 to 0.61 . The internal consistency coefficient of the scale was 0.85 .

The Educational Social Network Usage Self-Efficacy Scale developed by Teke and Özkılıç (2016) and consisted of 24 items and a 5-point Likert type was used. There are 3 factors in the scale: "Self-Efficacy in Using the Internet and Social Networking", "Undergraduate Education", and "Self-Sufficiency in Using Social Networking for Educational Purposes in Future Occupations". Teke and Özkılıç (2016) revealed that the first part with 12 questions explained $67.6 \%$ of the total variance and the second part with 8 items explained $62 \%$ of the total variance. The internal consistency coefficient of the scale was 0.89 .

The semi-structured interview form, which was developed by the researcher of this study, was used to collect qualitative data about the social media perceptions of the instructors. Interview form consisted of 13 questions. In order to collect qualitative data, 16 instructors (13 female and 3 male) were asked to respond through writing their answers to the questions in the interview form.

\section{Data Analysis}

The data collected from 2 scales had different number of items in each factor, and the factor and total scores were converted to the lowest 20 and the highest 100 for an easier comparison. The collected data were analyzed by SPSS 25 program. After KolmogorovSmirnov test, $\mathrm{p}>0.05$ was obtained. Moreover, skewness and kurtosis values were within \pm 1 range. Accordingly, it was concluded that the data was normally distributed. In order to find the answers to the research questions, the collected data were analyzed by using the frequency, percentage, arithmetic mean, standard deviation, $t$ test and Pearson Correlation analyses.

In the research, the data collected by semi-structured interview form was used to further expand and deepen the findings obtained with quantitative research to come up with the results accordingly.

\section{Findings}

\section{Quantitative Findings}

The findings of the instructors' attitudes towards social media and the perceptions of self-efficacy of social networks are summarized in Table 2. 
Table 2. Instructors' Attitudes towards Social Media and Self-efficacy for Educational Use of Social Networks

\begin{tabular}{|c|c|c|c|c|c|c|}
\hline Variables & & $N$ & $\bar{X}$ & $S . D$ & $\operatorname{Min}$ & $\operatorname{Max}$ \\
\hline \multirow{5}{*}{$\begin{array}{l}\text { Attitude to } \\
\text { Media }\end{array}$} & Need for Sharing & \multirow{8}{*}{54} & $\overline{57.9}$ & 13.6 & 20.0 & 82.5 \\
\hline & Social Competence & & 69.1 & 12.4 & 46.7 & 100.0 \\
\hline & Social Isolation & & 54.1 & 17.2 & 20.0 & 93.3 \\
\hline & Relationship with Teachers & & 72.8 & 14.9 & 33.3 & 100.0 \\
\hline & Total & & 71.1 & 12.3 & 39.0 & 96.0 \\
\hline \multirow{3}{*}{ Self-sufficiency } & Social Network & & 71.8 & 18.6 & 20.0 & 100.0 \\
\hline & Career & & 72.9 & 17.9 & 35.0 & 100.0 \\
\hline & Total & & 72.1 & 16.3 & 30.0 & 100.0 \\
\hline
\end{tabular}

Table 2 shows that the attitude of the instructors towards social media is between 39 and 96; the arithmetic mean is 71.1. In terms of factors, the arithmetic mean of "Need for Sharing" is 57.9, the "Social Competence" factor is 69.1 , the "Social Isolation" factor is 54.1, and the "Relationship with the Teachers" is 72.8. Accordingly, it can be said that instructors have high attitudes towards "Social Network", and the lowest mean belongs to the "Social Isolation" factor, and the highest arithmetic mean belongs to the "Relationship with Teachers" factor.

Table 2 shows that self-efficacy scores of instructors for educational use of social media are between 30 and 100; the arithmetic mean is 72.1. In terms of factors, the arithmetic mean for "Social Network" factor is 71.8 and the arithmetic mean for "Career" factor is 72.9. According to these scores, it can be expressed that instructors' perceptions of self-efficacy for educational use of social media are sufficiently high. The findings of the instructors' attitudes towards social media and their self-efficacy towards the educational use of social networks distribution according to gender are summarized in Table 3.

Table 3. Attitudes and Self-Efficacy of Instructors According to Gender Variable

\begin{tabular}{|c|c|c|c|c|c|c|c|}
\hline Attitudes / Section & Gender & $N$ & $\bar{x}$ & $S S$ & $t$ & $d f$ & $p$ \\
\hline \multirow{2}{*}{ Need for Sharing } & Female & 20 & 60.6 & 11.6 & \multirow{2}{*}{1.045} & & \multirow{2}{*}{0.301} \\
\hline & Male & 33 & 56.6 & 14.7 & & & \\
\hline \multirow{2}{*}{ Social Competence } & Female & 20 & 68.7 & 10.3 & \multirow{2}{*}{-0.232} & & \multirow{2}{*}{0.818} \\
\hline & Male & 33 & 69.5 & 13.8 & & & \\
\hline \multirow{2}{*}{ Social Isolation } & Female & 20 & 57.7 & 15.5 & \multirow{2}{*}{1.119} & & \multirow{2}{*}{0.268} \\
\hline & Male & 33 & 52.2 & 18.1 & & & \\
\hline \multirow{2}{*}{ Relationship with Teachers } & Female & 20 & 67.7 & 14.9 & \multirow{2}{*}{-1.957} & & \multirow{2}{*}{$0.05^{*}$} \\
\hline & & & & & & 51 & \\
\hline Total & Male & 33 & $\begin{array}{l}1.25 \\
705\end{array}$ & $\begin{array}{l}10.2 \\
13.6\end{array}$ & 0.506 & & 0.615 \\
\hline \multirow{2}{*}{ Social Network } & Female & 20 & 69.3 & 19.6 & \multirow{2}{*}{-1.116} & & \multirow{2}{*}{0.272} \\
\hline & Male & 33 & 74.8 & 15.8 & & & \\
\hline \multirow{2}{*}{ Career } & Female & 20 & 75.0 & 13.9 & \multirow{2}{*}{0.592} & & \multirow{2}{*}{0.557} \\
\hline & Male & 33 & 71.9 & 20.2 & & & \\
\hline \multirow{2}{*}{ Total } & Female & 20 & 70.8 & 16.9 & \multirow{2}{*}{-0.765} & & \multirow{2}{*}{0.448} \\
\hline & Male & 33 & 74.1 & 14.5 & & & \\
\hline
\end{tabular}

In Table 3 there is a significant difference between the "Relationship with Teachers" factor scores $\left(t_{(51)}=-1,957, p<0,05\right)$ in terms of their attitudes towards social media according to their gender, and there is no difference between the scores related to other factors. According 
to arithmetic mean, differentiation is in favour of male instructors. Therefore, it can be said that male instructors are more willing to use social media to establish relationships with their colleagues than female instructors. However there is no difference in the self-efficacy of the instructors regarding the educational use of social networks in terms of both total scores and factor scores. Accordingly, it can be said that the self-efficacy of the instructors for the educational use of social networks is similar in terms of their gender. The findings of the instructors' attitudes towards social media and whether their self-efficacy for educational use differs according to age ranges are demonstrated in Table 4.

Table 4. Attitudes and Self-Efficacy of Instructors According to Age Variable

\begin{tabular}{|c|c|c|c|c|c|c|c|}
\hline Attitudes / Section & Age & $\mathbf{N}$ & $\overline{\mathbf{X}}$ & SD & $\mathbf{T}$ & df & $\mathbf{p}$ \\
\hline \multirow{2}{*}{ Need for Sharing } & $18-40$ & 36 & 58.1 & 12.9 & \multirow{2}{*}{0.150} & \multirow{2}{*}{\multicolumn{2}{|c|}{0.917}} \\
\hline & 40 and above & 18 & 57.6 & 15.3 & & & \\
\hline \multirow{2}{*}{ Social Competence } & $18-40$ & 36 & 68.6 & 11.3 & \multirow{2}{*}{-0.437} & \multirow{2}{*}{\multicolumn{2}{|c|}{0.664}} \\
\hline & 40 and above & 18 & 70.2 & 14.6 & & & \\
\hline \multirow{2}{*}{ Social Isolation } & $18-40$ & 36 & 54.6 & 16.3 & \multirow[b]{2}{*}{0.371} & \multirow{2}{*}{\multicolumn{2}{|c|}{0.712}} \\
\hline & 40 and above & 18 & 52.8 & 19.2 & & & \\
\hline Relationship with Teachers & $\begin{array}{l}18-40 \\
40 \text { and above }\end{array}$ & $\begin{array}{l}36 \\
18\end{array}$ & $\begin{array}{l}70.6 \\
77.4\end{array}$ & $\begin{array}{l}16.2 \\
10.8\end{array}$ & -0.620 & 52 & 0.111 \\
\hline Total & $\begin{array}{l}18-40 \\
40 \text { and above }\end{array}$ & $\begin{array}{l}36 \\
18\end{array}$ & $\begin{array}{l}70.8 \\
71.6\end{array}$ & $\begin{array}{l}11.1 \\
14.8\end{array}$ & -0.217 & & 0.829 \\
\hline Social Network & $\begin{array}{l}18-40 \\
40 \text { and above }\end{array}$ & $\begin{array}{l}36 \\
18\end{array}$ & $\begin{array}{l}73.6 \\
68.1\end{array}$ & $\begin{array}{l}18.6 \\
18.5\end{array}$ & 1.036 & & 0.305 \\
\hline Career & $\begin{array}{l}18-40 \\
40 \text { and above }\end{array}$ & $\begin{array}{l}36 \\
18\end{array}$ & $\begin{array}{l}74.1 \\
70.6\end{array}$ & $\begin{array}{l}17.9 \\
18.1\end{array}$ & 0.669 & & 0.506 \\
\hline Total & $\begin{array}{l}18-40 \\
40 \text { and above }\end{array}$ & $\begin{array}{l}36 \\
18\end{array}$ & $\begin{array}{l}73.7 \\
68.7\end{array}$ & $\begin{array}{l}16.8 \\
15.2\end{array}$ & 1.072 & & 0.289 \\
\hline
\end{tabular}

Examining Table 4, no significant difference between the levels of attitude towards social media according to the age of the instructors is diagnosed and there is no difference between the arithmetic means related to other factors. Accordingly, it can be said that the level of attitude towards social media according to their age is similar in terms of their age. According to the Table 4, there is no significant difference in the self-efficacy of instructors about the educational use of social networks in terms of both total scores and factor scores. Accordingly, it can be said that instructors' self-efficacy for the educational use of social networks is similar in terms of their age. Table 5 shows the findings of the participants' attitudes towards social media and whether their self-efficacy towards the educational use of social networks differs according to their educational status.

Table 5. Attitudes and Self-Efficacy of Instructors According to Educational Status Variable

\begin{tabular}{|c|c|c|c|c|c|c|c|}
\hline Attitudes/Section & $\begin{array}{l}\text { Education } \\
\text { Level }\end{array}$ & $\mathbf{N}$ & $\overline{\mathbf{X}}$ & SD & $\mathbf{T}$ & df & $\mathbf{p}$ \\
\hline Need for Sharing & $\begin{array}{l}\text { High School } \\
\text { University }\end{array}$ & $\begin{array}{l}21 \\
33\end{array}$ & $\begin{array}{l}59.0 \\
57.2\end{array}$ & $\begin{array}{l}14.6 \\
13.0\end{array}$ & 0.485 & & 0.630 \\
\hline Social Competence & $\begin{array}{l}\text { High School } \\
\text { University }\end{array}$ & 21 & $\begin{array}{l}69.5 \\
68.9\end{array}$ & $\begin{array}{l}14.0 \\
11.5\end{array}$ & 0.182 & & 0.856 \\
\hline Social Isolation & $\begin{array}{l}\text { High School } \\
\text { University }\end{array}$ & $\begin{array}{l}21 \\
33\end{array}$ & $\begin{array}{l}56.2 \\
52.6\end{array}$ & $\begin{array}{l}21.0 \\
14.4\end{array}$ & 0.741 & 52 & 0.462 \\
\hline Relationship with Teachers & $\begin{array}{l}\text { High School } \\
\text { University }\end{array}$ & $\begin{array}{l}21 \\
33\end{array}$ & $\begin{array}{l}77.8 \\
69.7\end{array}$ & $\begin{array}{l}12.0 \\
15.8\end{array}$ & 2.001 & & $0.050^{*}$ \\
\hline Total & $\begin{array}{l}\text { High School } \\
\text { University }\end{array}$ & $\begin{array}{l}21 \\
33 \\
\end{array}$ & $\begin{array}{l}73.0 \\
69.8\end{array}$ & $\begin{array}{l}14.0 \\
11.1\end{array}$ & 0.934 & & 0.354 \\
\hline Social Network & High School & 21 & 65.5 & 21.2 & -2.039 & & $0.047^{*}$ \\
\hline
\end{tabular}

PER Participatory Educational Research (PER) 


\begin{tabular}{lllllll} 
& University & 33 & 75.8 & 15.8 & & \\
\multirow{2}{*}{ Career } & High School & 21 & 72.9 & 20.2 & -0.004 & 0.997 \\
\multirow{2}{*}{ Total } & University & 33 & 72.9 & 16.6 & & $0.050^{*}$ \\
\hline
\end{tabular}

In Table 5, there is a significant difference between the attitude scores of "Relationship With Teachers" according to their education level $\left(t_{(52)}=2,001, p<0,05\right)$ and there is no difference between the points related to other factors. When the arithmetic means are examined, the differentiation is in favour of the instructors in the high school and below. According to this, it is possible to say that the instructors at high school and below are more willing to use social media to establish a relationship with their colleagues than the instructors at upper secondary level. In terms of the self-efficacy of the instructors towards the educational use of social networks, there is a significant difference between the self-efficacy scores for the use of social networks $\left(t_{(52)}=-2,039, p<0,05\right)$, and there is no difference between the scores of other factors. When the arithmetic means are examined, the differentiation is in favour of the instructors at the upper secondary level. According to this, the trainers at the upper secondary level have more self-efficacy to use of social networks than the instructors at high school level or below. The attitudes of the instructors towards social media and the findings of their self-efficacy towards the educational use of social networks according to their marital status are summarized in Table 6.

Table 6. Attitudes and Self-Efficacy of Instructors According to Marital Status Variable

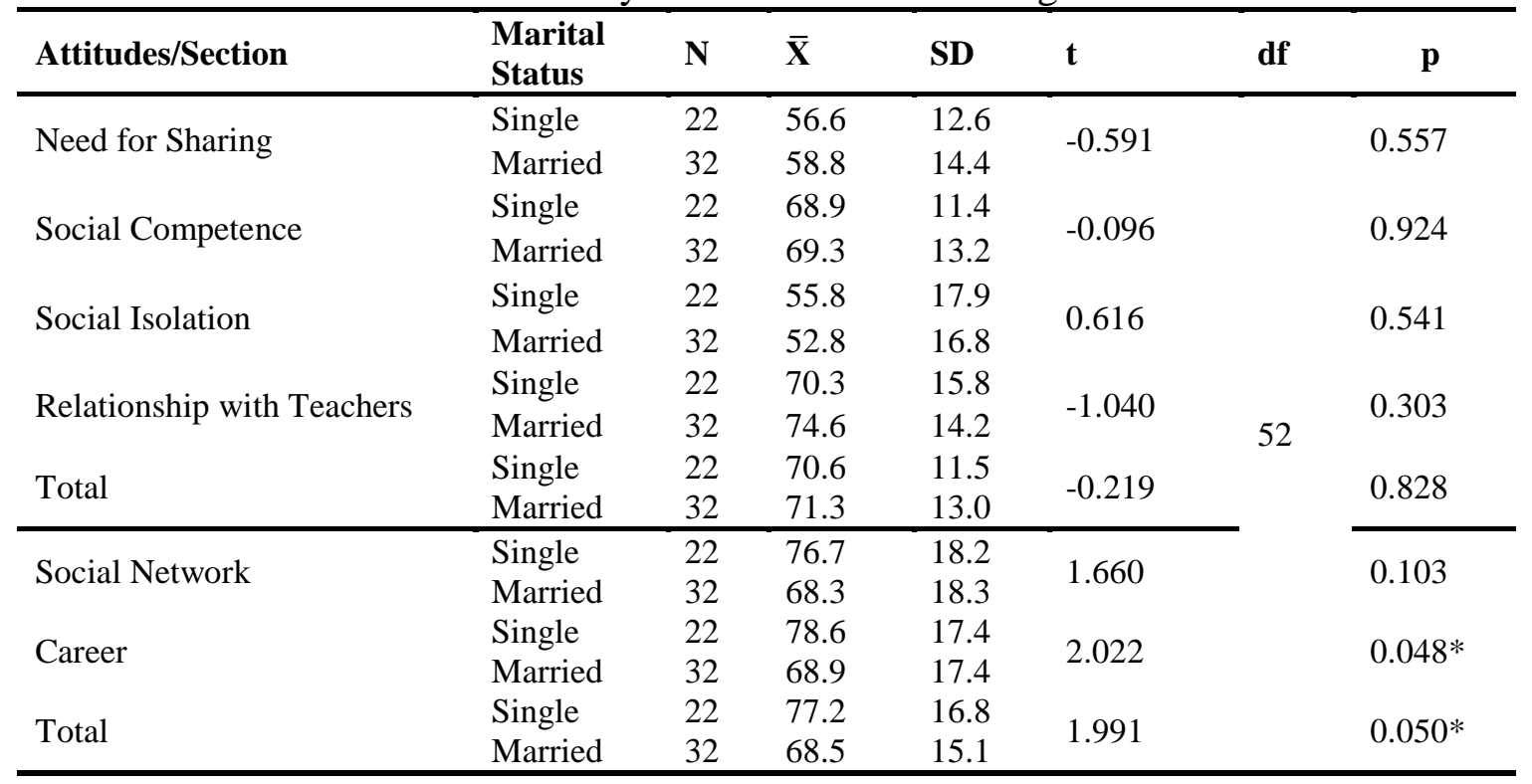

When Table 6 is examined, no significant difference between the levels of attitudes towards social media according to the marital status of the trainers and no difference between the scores of other factors are detected. According to the marital status of the trainers, the level of attitude towards social media is similar in terms of their marital status. In terms of selfefficacy of instructors on educational use of social networks, there is a significant difference between self-efficacy scores $\left(t_{(52)}=2,022, p<0,05\right)$ for educational purposes and social networks in terms of self-efficacy, there is no difference between scores related to other factors. When the arithmetic means are examined, differentiation is in favour of single instructors. According to this, it can be said that single instructors have more self-efficacy to use social networks for educational purposes in their professional lives than married instructors. The results of the Pearson Correlation analysis are indicated in Table 7 pertaining 
to the relationship between social media attitudes and social self-efficacy for educational use of social networks.

Table 7. The Relationship between Social Media Attitudes and Social Self-Efficacy for Educational Use of Social Networks

\begin{tabular}{|c|c|c|c|c|c|c|c|c|}
\hline & & $\begin{array}{l}\text { Need } \\
\text { Sharing }\end{array}$ & for & $\begin{array}{l}\text { Social } \\
\text { Competence }\end{array}$ & $\begin{array}{l}\text { Social } \\
\text { Isolation }\end{array}$ & $\begin{array}{l}\text { Relationship } \\
\text { Teachers }\end{array}$ & with & Total \\
\hline \multirow{3}{*}{ Social Network } & $\mathrm{R}$ & .205 & & .143 & .137 & -.148 & & .165 \\
\hline & $\mathrm{p}$ & .137 & & .302 & .322 & .287 & & .234 \\
\hline & $\mathrm{N}$ & 54 & & 54 & 54 & 54 & & 54 \\
\hline \multirow{3}{*}{ Career } & $\mathrm{r}$ & .312 & & .115 & .363 & -.035 & & .318 \\
\hline & $\mathrm{P}$ & $.022 *$ & & .407 & $.005 *$ & .803 & & $.019 *$ \\
\hline & $\mathrm{N}$ & 54 & & 54 & 54 & 54 & & 54 \\
\hline \multirow{3}{*}{ Total } & $\mathrm{r}$ & .261 & & .154 & .217 & -.136 & & .228 \\
\hline & $\mathrm{p}$ & $.050 *$ & & .266 & .115 & .327 & & .097 \\
\hline & $\mathrm{N}$ & 54 & & 54 & 54 & 54 & & 54 \\
\hline
\end{tabular}

In Table 7, when the relationship between social media attitudes and self-efficacy of social networks is examined, a significant positive relationship between the "Need for Sharing" of instructors and the use of social networks for education $(p<0.05, r=0.312)$ is found. In addition, there is a significant positive relationship between the "Social Isolation" of the instructors and the use of social networks for educational purposes $(p<0.05, r=0.363)$. When the correlation coefficients are examined, it is observed that the relationship at all levels is not very large.

\section{Qualitative Findings}

According to the qualitative findings, it is concluded that participants use Facebook, Instagram, WhatsApp and YouTube, and only 1 participant uses Twitter. In order to find an answer to "What are the views of instructors on social media?" question, qualitative data collected using interview forms and the content analysis method is used to analyse data. As a result, the following 6 main themes are formed:

- The Aim of Social Media Usage

- The Importance of Social Media for Individuals

- The Effects of Social Media on Individuals' Life Styles

- The Effect of Social Media on Everyday Life Skills

- Use of Social Media in Education

- Positive and Negative Sides of Social Media

- Limitations of Social Media

According to the" intended uses of social media", which is the first main theme, all participants stated that they used social media tools to communicate with their friends and family members. For example, P2 said that "I use WhatsApp frequently to reach more than one person simultaneously for communication purposes". Moreover, participants use social media to follow people, share photos, share their feelings and thoughts, and share situations. In this regard, P9 stated that "I use my social media accounts for shopping, getting information about educational purposes, communication, sharing about my business life and to talk to my friends whom I have not seen for a long time". In addition, all of the instructors stated that they used social media for educational purposes, for their personal development 
and professional development. In this context, P10 said "I use social media to gain new knowledge in terms of my field" and he continued "I use YouTube to evaluate the new activities used in various toy productions and pre-school education". 5 of the participants also stated that they used social media for shopping.

Considering the second theme which was "the importance of social media for individuals", all of the participants emphasized that social media plays an important role in communicating with friends and family members. According to the participant answers, social media made it easier to contact distant family members. Again, for the majority of the participants, it seemed that to be followed and appreciated through social media became a matter of being esteemed. Participants also stated that they used social media to improve themselves both personally and professionally. P7 underlined "I am doing research on my job, collecting information and sharing the information I am looking for". 2 participants attached importance to the use of social media because they said could easily share their feelings and thoughts. For example, P13 said "The sharing of feelings and thoughts that are important to me is more important than being followed and communicating with people who share the same idea with me or with the ones who do not is also meaningful for me". Only 1 of the participants stated that social media was a trivial tool for him.

When we look at "the effects of social media on the life styles of individuals", we see that it facilitated the communication of the participants with their family members and friends. All of the participants stated that they could easily access the content required for educational purposes and professional development through social media. 3 of them stated that it was important for them to be followed and admired on social media. For example P6 said that "Sharing in my social media accounts is important to be appreciated by a large number of people". P12 and P13 stated that they could easily explain what they could not tell in their lives through social media sharing and they could share their feelings and thoughts clearly. P13 explained this situation as "It allows me to express my feelings and thoughts in a more comfortable way with a message or any other social media tool. I can say that I'm happy with sharing a story or expressing my anger in conveying my sadness. Sometimes people feel lonely. It's important to have a nice chat with my friends who say they will be there for me with a touch of a button".

Considering another theme which was "the impact of social media on daily life skills", all of the participants stated that they used social media for the development of professional skills. Similarly, 2 of the participants stated that they used social media to improve their animal care and plant care skills. For example, P1 said that "since I prefer a natural and peaceful life, planting and feeding animals and realizing these purposefully makes me even happier". 2 of the participants mentioned that they learned about sports activities through social media and that they could do these at home again using social media. Also, they mentioned that "... has fostered my being more active in daily life. I think I will be healthier with a balanced diet and being involved in sports activities". They also stated that they used social media to increase their world knowledge. Female participants mentioned that they used social media to follow fashion, shopping and looking at recipes.

Considering the fifth theme, "the use of social media in education", participants stated that social media was a tool that might be used for accessing and sharing educational materials. P16 supported that "Social media can be used in education. Because the impact area is very wide and the speed of the information delivery is very fast", P3 also said that "Information exchange can be realized by sharing course topics via social media", P7 stated "By sharing 
information, social media can be useful in the form of a question and answer", P10 said "I believe that social media can be used in educating individuals and it will be more effective visually. To share the knowledge and documents about their branches on social media accounts and to increase the success of the individuals through constant interaction is possible". It is also mentioned that online training can be given via social media. Today, many courses are indeed offered online to students. P1 supported this saying "Courses can be given by live broadcast from social media accounts. It is like a distance learning system. In addition, after the subject is focused on in the lessons, pre-determined YouTube videos can be used to support the very process visually". They stated that they used social media to communicate with students / trainees.

According to findings related to positive and negative aspects of social media, which is the sixth main theme, the positive aspects of social media were given as inherent opportunities to reach the information required for personal / professional development quickly and easily. For example, P3 stated that "I can do research in my own field. I have access to the information I am looking for or I can share any knowledge with my friend with the help of social networks". In addition, the possibility of easy communication with family members and friends was also mentioned as another positive feature. It was also stated by the participants that sharing emotions and thoughts easily was a plus of social media. The convenience of shopping was also a positive feature of the social media articulated by the participants. P6 said that "Sometimes, I do shopping. It is nice to be able to find anything through the Internet when I cannot find something in my surroundings". On the other side, some negative aspects of social media are stated such as unconscious uses that might cause a loss of time. Moreover, the excessive use of social media was linked to Internet addiction. Another point enunciated by the participants was that excessive use of social media made individuals forget about the responsibilities that they had to fulfil. P5 explained this negativity as "Especially bearing in mind fact that the young population devotes the majority of their time to social media accounts, especially with the widespread use of smart phones, we can say individuals cannot fulfil their responsibilities for themselves and others that are for their environment". Depending on the use of excessive social media, individuals' real social bonds have weakened and virtual relationships have become common. P10 said "People's excessive use of social media can take individuals away from real life, leaving them with weaker and unhappy human relationships". There are different opinions related to potential limitations to social media though. 7 participants thought that there had to be no limitations or control over social media. 6 participants stated that the content of social media (harmful sharing and applications, slang word use and advertisements) had to be restricted. 2 participants mentioned the possibility of age restrictions and 1 told that social media had to be restricted completely.

\section{Conclusion and Discussion}

As a result of the quantitative and qualitative findings obtained in the study, it is observed that the instructors have a high level of attitude and ability to use social media. When we look at the literature, this result is similar to those of the previous studies. Most of the instructors use social media for personal and professional purposes (Kilis, Rapp \& Gülbahar, 2014). In terms of factors, the results were low-level in the "Social Isolation" dimension, while Aküzüm and Saraçoğlu (2017)'s research findings are higher in that sense. "Relationship with Teachers" and "Social Competence" dimensions of the study appeared on top although in Aküzüm and Saraçoğlu (2017)'s research they were the lowest. In both studies, the sub-dimension "Needs for Sharing" emerged at a medium level. 
As a result, it was seen that instructors used social media effectively in the instructional field. Teachers' perceptions of self-efficacy towards the educational use of social media were sufficiently high. As was also stated by Öztürk and et al. (2016), the reasons for the use of social media by instructors were mostly linked to the wish to benefit from chances offered by social media for educational purposes. In the literature, instructors seem to use social media for educational and informational purposes (Akkoyunlu, 2002; Atav, Akkoyunlu \& Sağlam, 2006; Kaya \& Durmuş, 2010; Sat1l, 2011; Horzum, 2010). Similarly, according to qualitative findings, it can be said that the instructors used social media for personal and professional development and for their lessons.

Looking at the other results of this study, a significant differentiation was found in the subdimension of "Relationship with Teachers" on social media. According to the analysed data, it can be said that male instructors were more willing to use social media to establish relationships with their colleagues than female instructors. In the literature, according to Ili (2013), gender factor is a variant in social media usage needs. Argin (2013) found that the differences were in favour of male students, which matched the results of this study. However, there are different results found in the literature. For instance, research has shown that women are also active social media users (McAndrew \& Jeong, 2012). In some other studies, gender variable does not seemingly cause any significant difference (Köroğlu, 2014). Hence it can be said that instructors' self-efficacy towards the educational use of social networks is similar in terms of gender. Acar and Yenmiş (2014) found similar results in their study as well.

In light of the results, it was seen that there was no significant difference between the level of attitudes of the instructors towards social media according to their age and Acar and Yenmiş (2014) reached similar results in their study. Alakurt (2016) also stated that social media usage did not show a statistical difference according to age. Thusly, it can be said that the self-efficacy of the instructors for the educational use of social networks was similar in terms of age. Considering the arithmetic means, it can be underpinned that instructors were highly qualified for the educational use of social media. The reason for this was that all instructors wanted to increase their professional development through social media and to transfer their knowledge to learners and to increase communication and interaction with learners. Studies that are conducted on this subject support these results (Lim, Agostinho, Harper, Chicharo, 2014; Ng, Wong, 2013; Ratneswary, Rasiah, 2013; Kabilan, Ahmad, Abidin, 2010; McCarthy, 2010; Ellison, Steinfield, Lampe, 2007). Similar to quantitative findings, qualitative results also showed that there was no difference in age with regard to social media use for educational purposes.

According to the instructors at high school and below the level of education at the upper secondary level, the instructors were more willing to use social media to engage with their colleagues. Instructors, who had a university degree, were more self-sufficient in the educational use of social networks than high school and lower education level instructors. In the literature, $80 \%$ of respondents stated that they used social media to learn and for personal training (Whiting \& Williams, 2013). In another study, it was found out that high school students use social media as a source / a platform for material sharing and for communication and educational purposes (Tanrıverdi \& Sağır, 2014).

The attitude levels towards social media were similar in terms of their marital status. Alakurt (2012) reached a similar result. Single instructors had more self-efficacy to use social networks for educational purposes in their professional lives than married instructors. Koçak 
(2012) stated that singles used social media more than married ones.

Likewise, there was a significant positive relationship between the "Need for Sharing" of instructors and the use of social networks for educational purposes in their professional lives. In a study conducted on nurses, it was observed that social media was used for professional development and knowledge sharing in their fields (Ergün, Keskin, 2017; Levati, 2014). There was also a significant positive relationship between "Social Isolation" of instructors and the use of social networks for educational purposes. Again, when looking at nurses as a professional group, the ones who had difficulty in joining their professional communities in working environments could easily reach professional organizations via social media (Ergün, Keskin, 2017). However, there was no relationship between other factors.

According to qualitative results of this research, the instructors used social media for communication, professional and personal development, follow-up / sharing, sharing photos, sharing feelings and thoughts, sharing information and shopping. Similarly, Gürkaynak, Doğan, Barutçu, Haşıloğlu (2016) concluded that university students and academics use social media to communicate, share information, share views, share photos and shop. With their research on nurses, Korkmaz, Kılıç, Demiray, Hablemitoğlu, Gürkan, Yücel, Kırık (2015) also found that social media were used for professional development, research and sharing information.

Obviously, participants not only talked about the positive aspects of social media, but also the negative ones. They also emphasized that social media had harmful effects besides its useful aspects. Unconscious and excessive uses, dependence, negligence of responsibilities and weakening of social relations were mentioned as such. Similarly, Korkmaz et al. (2015) stated that using social networks excessively reduces human relations and also emphasizes that individuals might neglect their responsibilities for family and for work. Correlation results between the dependency of daily social media usage and dependence of individuals showed that there was a positive relationship between them (İnce \& Koçak, 2017). Conjointly, the results of this study showed that the participants had positive thoughts about integrating social media and educational environments. The instructors stated that the social media could be used to enrich the classroom environment and to increase the interaction and communication by providing more and active participation of the trainees. Many previous studies also support these results (Lim, Agostinho, Harper, Chicharo, 2014; Ng, Wong, 2013; Ratneswary, Rasiah, 2013; Kabilan, Ahmad, Abidin, 2010; McCarthy, 2010; Ellison, Steinfield, Lampe, 2007).

It is believed that this study will make a contribution to the related literature. Surely so as to be able to further subsidize the literature, qualitative research can be conducted through which the social media use of instructors in lifelong learning courses can be observed comprehensively. Aside from that, instructor uses of social media in courses and the impact of this on learners and learning can be investigated using experimental methods.

\section{References}

Acar, S., Yenmiş, A. (2015). A Research Study on Determine of Students Opinions for Social Networks in Education: Sample Study of Facebook. Ejovoc (Electronic Journal of Vocational Colleges), 4 (3), doi: 10.1501/OTAM_0000000371

Akbaş, O., Özdemir, S. M. (2002). Lifelong learning in the European Union. Journal of MoNE, $155-156,112-126$. 
Akkoyunlu, B. (2002). Use of Internet by Teachers and Their Opinions on the Issue. Hacettepe University Journal of Education Faculty, 22: 1-8. Retrieved from http://dergipark.gov.tr/hunefd/issue/7814/102593

Aktan, C. (2007). Change in Higher Education: Global Trends and New Paradigms. Yaşar University Publication. İzmir.

Alakurt, T. (2012). Investigating Teacher Candidates' Motivation for Social Media Use and Learning Styles. Ankara University, Journal of Faculty of Educational Sciences, Year: 2016, 49(1), 43-63, doi: 10.1501/Egifak_0000001374

Argin, F. S. (2013). Examination of the Attitudes of Secondary and High School Students Towards Social Media: Çekmeköy Sample. Unpublished Master's Thesis, Yeditepe University Institute of Social Sciences, İstanbul.

Atav, E., Akkoyunlu B., Sağlam, N. (2006). Prospective Teachers' Internet Access Facilities and Their Internet Usage. Hacettepe University Journal of Education Faculty. 30: 3744. Retrieved from http://dergipark.gov.tr/hunefd/issue/7806/102363

Axboe, Mette K., Christensen, Kaj S., Kofoed, Poul-Erik \& Ammentorp, Jette. (2016). Development And Validation Of A Self-efficacy Questionnaire (SE-12) Measuring The Clinical Communication Skills Of Health Care Professionals, BMC Medical Education, 16 (272), 1-10.

Aydın, M. Çelik, T. (2017). Investigation of Social Media Usage and Satisfaction of Social Studies Student Teachers. International Journal of Educational Theory and Practice, $3(2), 82-97$

Aziz, A. (1994). Research Methods, Techniques and Communication. Turhan Bookstore Ankara, 28.

Bandura, Albert. (1997). Self-Efficacy: Toward a Unifying Theory of Behavioral Change. Psychological Review, 84(2), 191-215.

Boyd, D. (2008). American Teen Sociality in Networked Publics. Unpublished Ph. D. Thesis, University of Berkeley.

Büyüköztürk, Ş., Kılıç Çakmak, E., Akgün, Ö.E., Karadeniz, Ş. ve Demirel, F. (2016). Scientific Research Methods. 21. Edition, Pegem Academy, Ankara.

Cheallaigh, M.N. (2001). Life long learning-how the paradigm has changed in the 1990s. (Eds. Descy, P \& Tessaring M.) Training in Europe. Volume 1. Luxembourg: Office for Official Publication of the European Communities.

Egüz, Ş. ve Kesten, A. (2018). Identification of Perceptions of Social Media in StudentTeachers of Social Studies Through Metaphors. Cumhuriyet International Journal of Education, 7(3), 219-240. http://dx.doi.org/10.30703/cije.403147

Ellison, N. B., Steinfield, C. ve Lampe, C. (2007). The Benefits of Facebook "Friends:" Social Capital and College Students' Use of Online Social Network Sites. Journal of Computer Mediated Communication, 12(4), 1143-1168.

Ergün, G. \& Keskin, B. (2017). Determining the Social Media Usage Characteristics of School of Health Students in Professional Organizations. Journal of Health Sciences, Acıbadem University, https://doi.org/10.31067/0.2018.80.

Gürkaynak, Ş., Doğan, N.S., Barutçu, S. \& Haşıloğlu, S.B. (2016). Changes in Social Media Applications in Terms of Usage Frequencies: A Comparative Study on Academicians and Student. Pamukkale Journal of Business and Information Management, 3(2):1-10

Horzum, M. B. (2010). Investigating Teachers' Web 2.0 Tools Awareness, Frequency and Purposes of Usage in Terms of Different Variables. International Journal of Human Sciences, 7(1): 603-633.

İli, K. (2013). Impact of Social Media Environments and Tools on Students Behaviours (Example of Gaziçiftliği Anatolian High School). Unpublished Master's Thesis, Hacettepe University Institute of Social Sciences, Ankara. 
İnce, M., Koçak, M. C. (2017). Social Media Habits of University Students: A Case of Necmettin Erbakan University. Karabük University Journal of Institute of Social Sciences, 7 (2), 736-749. Doi :http://dx.doi.org/10.14230/joiss430

Jones, N., Blackey, H., Fitzgibbon, K. ve Chew, E. (2010). Get Out Of Myspace!. Computers \& Education, 54 (3): 776-782. doi:10.1016/j.compedu.2009.07.008 http://learninginnovationexperts.pbworks.com/f/Get+out+of+my+space.pdf. Date of access: 28.10.2018.

Kabilan, M. K., Ahmad, N., Abidin, M. J. Z. (2010). Facebook: An Online Environment for Learning of English in Institutions of Higher Education? The Internet and Higher Education, 13(4), 179-187.

Kaya, S., Durmuş, A. (2010). Pre-Service Teachers' Perceived Internet Self-Efficacy and Levels of Internet Use for Research. Procedia-Social and Behavioral Sciences, 2(2): 4370-4376. doi:10.1016/j.sbspro.2010.03.695 http://www.sciencedirect.com/science/article/pii/S1877042810007354 Date of access: 08.12 .2018

Kilis, S., Rapp, C., Gülbahar, Y. (2014). Perception of Instructors about Social Media Usage in Higher Education: The Cases of Turkey and Germany. Journal of Instructional Technologies \& Teacher Education, 3(3): 20-28.

Koçak, N. G. (2012). Examination of Individuals' Behaviours and Motivations for Social Media Usage from the Perspective of Uses and Gratifications Approach: An Application in Eskişehir. Unpublished Ph. D. Thesis, Anadolu University Institute of Social Sciences, Eskişehir

Korkmaz, M., Kılıç, B., Demiray, E., Hablemitoğlu, Ş., Gürkan, A., Yücel, A.S., Kırık, A.M. (2015). An Applied Study: Nurses' Use of Social Media and the Level of Their Perceptions Concerning Their Jobs. International Refereed Journal of Humanities and Academic Sciences, 4(13), 59-84. Doi: 10.17368/UHBAB.2015139476

Köroğlu, İ. Ş. (2014). Social Media Usage Motivations of Gifted Children. Unpublished Master's Thesis, Istanbul Ticaret University, Institute Of Social Sciences, İstanbul

Levati, S. (2014). Professional Conduct among Registered Nurses in the Use of Online Social Networking Sites. Journal of Advanced Nursing, 70, 2284-2292. https://doi.org/10.1111/jan.12377

Lim, J.S.Y., Agostinho, S., Harper, B.; Chicharo, J. (2014). The Engagement of Social Media Technologies by Undergraduate Informatics Students for Academic Purpose in Malaysia. Journal of Information, Communication and Ethics in Society, 12(3): 177194.

Luszczynska, Aleksandra, Gutie'Rrez-DonA, Benicio \& Schwarzer, Ralf. (2005). General Self-Efficacy in Various Domains of Human Functioning: Evidence From Five Countries. International Journal of Psychology, 40(2), 80-89.

McAndrew, F. T., Jeong, H. S. (2012). Who Does What On Facebook? Age, Sex, and Relationship Status as Predictors of Facebook Use. Computers in Human Behavior, 28(6): 2359-2365. https://doi.org/10.1016/j.chb.2012.07.007

McCarthy, J. (2010). Blended Learning Environments: Using Social Networking Sites to Enhance the First Year Experience. Australasian Journal of Educational Technology, 26(6), 729-740.

MEB (2018). Ministry of National Education Lifelong Learning Institutions Regulation http://hbogm.meb.gov.tr/meb_iys_dosyalar/2018_04/11093946_MEB_HBO_KURU MLARI_YYNETMELYYY.pdf. Date of access: 28.11.2018

Morgil, İnci, Seçken, Nilgün ve Yücel, A.Seda. (2004). Investigation of Self-Efficacy Beliefs of Chemistry Teacher Candidates in Terms of Some Variables, Balıkesir University Journal of the Institute of Science and Technology, 6(1), 62-72. 
Ng, E.M.W.,Wong, H.C.H (2013). Facebook: More Than Social Networking for At-Risk Students. Procedia - Social and Behavioral Sciences, 73, 22-29

Onwuegbuzie, A. J., Collins, K. M. T. (2007). A Typology of Mixed Methods Sampling Designs in Social Science Research. The Qualitative Report, 12 (2), 281-316.

Otrar, M., Argin S.(2015). A Scale Development Study to Determine the Attitude of Students' Towards Social Media. Journal of Research in Education and Teaching, 2015 4(1).

Özmen, F., Aküzüm, C., Sünkür, M., Baysal, N. (2012). Functionality of Social Networks in Educational Settings. e-Journal of New World Sciences Academy NWSA-Education Sciences, 7, (2): 496-506.

Öztürk, M.F., Talas, M. (2015). Interaction of Social Media and Education. Journal of World of Turks-Zeitschrift für die Welt der Türken, 2015 7(1), 101-120.

Öztürk, S, D., Öztürk, F., Özen, R. (2016). Teachers' Use of Social-Media Tools for Their Professional Development. International Journal of Human Sciences, 13(1), 7-21. doi:10.14687/ijhs.v13i1.3515

Ratneswary, R., Rasiah, V. (2013). Transformative Higher Education Teaching and Learning: Using Social Media in a Team Based Learning Environment. Procedia - Social and Behavioral Sciences, 123(2014), 369-379.

Saraçoğu, M., Aküzüm, C. (2017). Investigation of Attitudes of University Students towards Social Media, Dicle University Journal of Ziya Gökalp Faculty of Education, 32:803817 Doi: http://dx.doi.org/10.14582/DUZGEF.789

Satıl, E. (2011). New Media and Socialization. Unpublished Master Thesis. Konya: Selçuk University

Stajkovic, Alexander D. \& Luthans, Fred. (1998). Self-Efficacy and Work-Related Performance: A Meta Analysi, Psychological Bulletin, 124(2), 240-261.

Şişman-Eren, E. (2014). Developing Social Media Use Purposes Scale and Examining Based on Some Personal Variables. Hacettepe University Journal of Education, 29(4), 230243.

Tanrıverdi, H., Sağır, S. (2014). The Impact of High School Students' Intentions in the Use of Social Media and The Way of Their Adoption of Social Media on Their Success. Adlyaman University Journal of Institute of Social Sciences, 18. https://dx.doi.org/10.14520/adyusbd.849

Teke, A., Özkılıç, R. (2016). Perceived Self-Efficacy of Pre-Service Teachers in Using Social Networks and The Internet for Educational Purposes. Uludag University Journal of Education Faculty, 29 (2), 303-323

Whiting, A., Williams, D. (2013). Why People Use Social Media: A Uses and Gratifications Approach. Qualitative Market Research: An International Journal, 16(4), 362-369. 